Article

\title{
Environmental Profile on Building Material Passports for Hot Climates
}

\author{
Amjad Almusaed 1,*(D), Asaad Almssad ${ }^{2}\left(\mathbb{D}\right.$, Raad Z. Homod ${ }^{3}(\mathbb{D})$ and Ibrahim Yitmen ${ }^{1(\mathbb{C}}$ \\ 1 Department of Construction Engineering and Lighting Science, Jönköping University, \\ 55111 Jönköping, Sweden; ibrahim.yitmen@ju.se \\ 2 Head of Building Technology, Karlstad University Sweden, 65188 Karlstad, Sweden; asaad.almssad@kau.se \\ 3 Department of Oil and Gas Engineering, Basrah University for Oil and Gas, Garmat Ali Campus, \\ Basrah 61004, Iraq; raadahmood@yahoo.com \\ * Correspondence: amjad.al-musaed@ju.se; Tel.: +46-70-045-1114
}

Received: 20 March 2020; Accepted: 27 April 2020; Published: 4 May 2020

\begin{abstract}
Vernacular building materials and models represent the construction methods and building materials used in a healthy manner. Local building materials such as gravel, sand, stone, and clay are used in their natural state or with minor processing and cleaning to mainly satisfy local household needs (production of concrete, mortar, ballast, silicate, and clay bricks and other products). In hot climates, the concept of natural building materials was used in a form that can currently be applied in different kinds of buildings. This concept depends on the proper consideration of the climate characteristics of the construction area. A material passport is a qualitative and quantitative documentation of the material composition of a building, displaying materials embedded in buildings as well as showing their recycling potential and environmental impact. This study will consider two usages of building materials. The first is the traditional use of building materials and their importance in the application of vernacular building strategies as an essential global bioclimatic method in sustainable architecture. The second is the affordable use of new building materials for their availability and utilization by a large part of society in a way to add more detail to research. The article aims to create an objective reading and analysis regarding specific building materials in order to generate a competent solution of materials that is suitable for building requirements in hot climates. This study evaluates the most suitable Building Material Passports needed in hot climates, where the environmental profile must be analyzed to confirm the use of natural materials.
\end{abstract}

Keywords: building materials; vernacular building; environmental design; ecological building materials

\section{Introduction}

The quality of today's architectural elements is influenced by the choice of building material from which the structures are made and the premises are finished. Buildings have a huge impact on the environment, and building materials generate environmental effects at their various life stages: during the manufacture of the materials, the construction phase, use and maintenance of the building, and the disposal or demolition phase. These environmental effects can take many different shapes [1]. The rapid development of our civilization has had a negative effect on our environment. The idea of sustainable development was proposed to help new generations [2]. All building materials are either environmentally friendly or emit some harmful substances.

Environmental requirements, first of all, correspond to natural materials, such as stone and wood, used by humans since ancient times. These materials are safe for human health while creating a favorable indoor microclimate. Environmental building materials are raw and processed nature-based materials used in the construction of the built environment. These materials are extracted from the biological 
cycle to serve technical purposes, and their production and processing result in low environmental impacts in terms of measures such as embodied energy and carbon, water consumption, and the use of harmful chemicals [3]. In warm climates, temperatures are more extreme, reaching records of approximately $45^{\circ} \mathrm{C}$ during the summer months of July and August. Consequently, many building material choices will be affected directly by the propriety of the material [4]. New constructions and restorations are associated with the use of building materials of various natures [5] that are more or less favorable for humans and also have different impacts on the environment. Owing to the increasing population, the increase in usage of building material has led to an increase in demand for new materials. Due to the shortage of materials, the conversion of wastes from industries as building materials has become a significant challenge. The recycling of such wastes as construction materials appears to be a practical solution for the effects of pollution and economical design of buildings [6]. Building materials must be selected in accordance with the quality required for a safe building, which is periodically updated with new materials that have received a certificate of environmental quality. What is meant by this term is actually an environmental and hygienic characteristic of the material. The basis of such an assessment is the presence or absence of harmful effects of the material on a person in the building in which this material is used [7]. To make a building more comfortable, it is necessary to choose the right material, given its heat-shielding properties specifically for building envelopes. Figure 1 shows building forms, structures, and materials for cold and hot climates. It is therefore crucial, when designing, to select efficient materials not only for economics and esthetics but also from an environmental point of view. This requires an environmental assessment and classification of building materials in accordance with environmental requirements. In this case, when deciding on the use of the material, it is necessary to be able to assess its direct and indirect impacts on the environment and humans from an environmental perspective. A wide range of building materials currently allows engineers to choose and give preference to the highest quality in environmental terms. Using the concept of a material passport optimizes building designs regarding resource use and the documentation of materials [8]. It contains a set of data describing the defined characteristics of materials in products, which allows for their efficient recovery, recycling, and re-use.

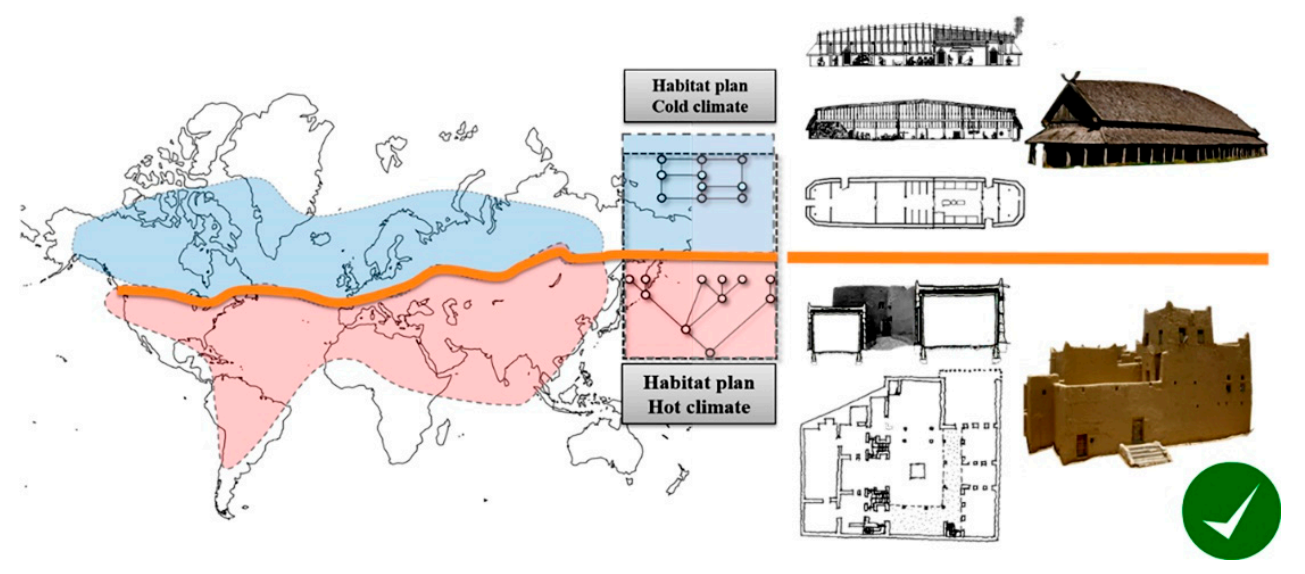

Figure 1. Building form, structure, and materials between cold and hot climates.

Environmental issues were neglected until recently, when they dramatically turned to a qualitative assessment of construction products [7,9]. Questions have arisen about what is required to build and finish buildings, what their features are in this process, and the impact on people and the environment.

This article is aimed at developing a mixture of solutions with useful materials to achieve the objective of the analysis: to generate a competent solution of building materials that is suitable for the buildings' specifics in hot climates. The rest of this article is organized as follows. Section 2 presents the passport sections on building material selection. Section 3 describes the traditional Building Material 
Passport. Section 4 depicts the contemporary requirements for building materials. Finally, Section 5 discusses the results with concluding remarks and future directions.

\section{Investigation Method}

The idea behind the method used to determine the health aspects is that the materials should not contain dangerous chemicals and, above all, should not release these to the indoor environment [10].

The environmental profile is based on the SBI (DK) calculation program, BEAT 2000, which is a standardized technique for classifying and measuring the environmental effects related to building materials during their life cycles [11]. The analysis depends on seven factors, and all the physical environmental impacts and effects are classified in two ways:

- Greenhouse effect, in which the environmental impacts of the resource benefits can be composed of a loss of resources and space consumption and risks of gas extraction or a cultivation process.

- Energy consumption, in which the environmental impact of the energy consumption considers the renewable feedstock energy and the heat of combustion of renewable resources.

The analysis will use the detailed knowledge about the embedded materials as well as the characteristics of building stocks to enable high recycling rates and low environmental impacts of buildings. To evaluate the building environmental impacts, it is necessary to consider all the life cycle phases: from the extraction of raw materials to their disposal [12]. The material passport serves as a design optimization tool and enables the generation and comparison of variants, thus supporting the decision-making process. A life cycle assessment (LCA) is a standard international method to analyze the environmental impacts of any product, process, or system. The LCA of a product is a technique to assess the environmental impact of its materials at all stages of its life cycle, from raw material extraction to production, use, repair and maintenance, and transportation, as well as waste burial or processing. Greenhouse gases (water vapor, carbon dioxide, methane, ozone, etc.) have the greatest impact on global climate change [13]. The environmental profile is about more than being able to offer some healthy material products. It is about the overall picture, all the surrounding processes, and the attitude, sincerity, and transparency to implement these values in a building process, as seen in Figure 2.

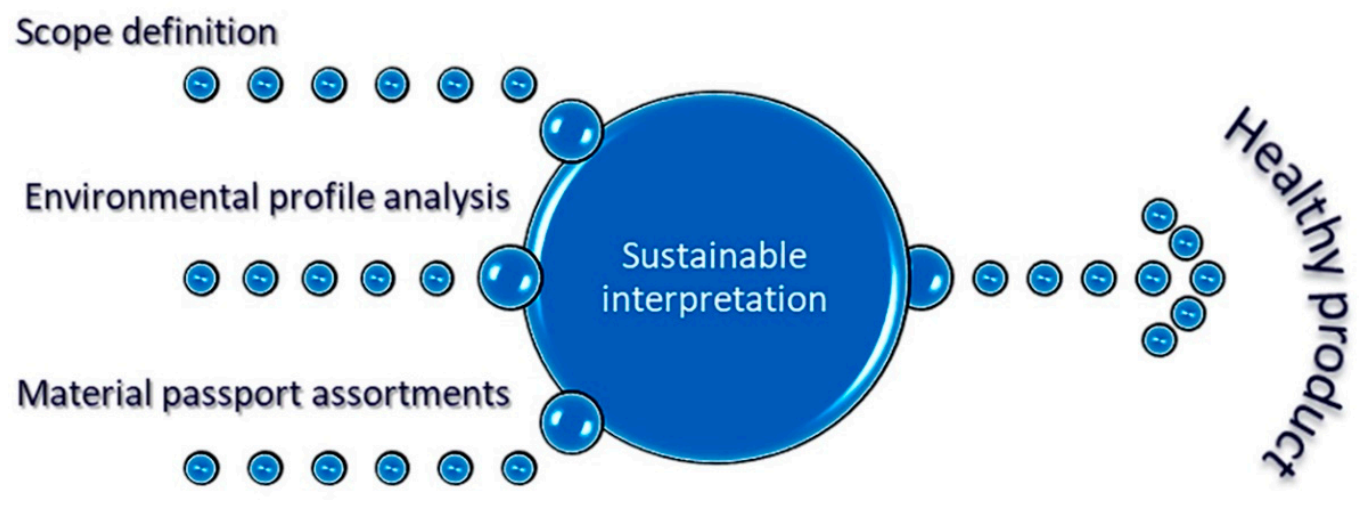

Figure 2. The methodological analysis according to the life cycle assessment phases.

The simpler the extraction, treatment, and purification used in the production of a material, the lower the energy consumption and, accordingly, the lower the volume of greenhouse gas emissions [11,14]. Choosing materials that use renewable energy sources (water, wind, sun) in their production significantly reduces the environmental impact of pollution and waste $[15,16]$. The production or procurement of building materials generally results in emissions of greenhouse gases as well as gases that contribute to the formation of precipitation in the form of acid rain. 


\section{Passport Sections on Building Material Selection}

A passport for building materials represents the safest way to consider materials required for the building process and also monitors safety during production. The Building Material Passport has to contain all the necessary information about the characteristics of materials for construction and the organization of production or work that maximally protect consumers and personnel from harmful health effects and industrial accidents. Figure 3 demonstrates the Building Material Passport's relation to the environmental profile

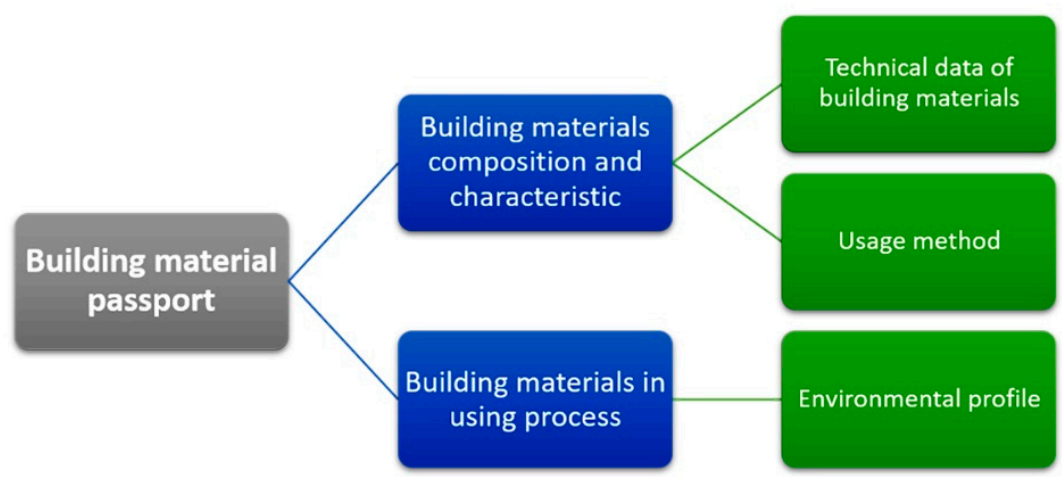

Figure 3. Building Material Passport's relation to the environmental profile.

In accordance with regulatory legal acts, a passport for a technical device is required. In the absence of a passport, the operation of a technical device is prohibited.

Building materials and products are materials and products that are used in the construction, repair and reconstruction of buildings (residential, public, industrial, etc.), structures (linear or areal facilities), as well as their components $[17,18]$. In the modern world, a huge number of various and diverse building materials are produced, differing in their technical characteristics, features of application and operation, which does not allow them to be unambiguous and briefly classified. However, there are a number of the most common types of classification according to the main features: the degree of preparedness, origin, composition, raw materials and destination. Accordingly, each material can be attributed to one or another group based on all classification criteria. The composition of building materials, similar to any substance, can be divided into mineral, organic, and combined (organic mineral) categories. The origin of building materials includes the processing depth of raw materials for their manufacture: natural materials are obtained by using materials found in the environment (wood, stone, sand, clay, etc.). The earth is our sustainer, the chain of ecological survival. Renewability is the key to our human continuum and our prime resource for architecture. Earth sheltering, earth handling, and earth escaping are more clearly pronounced in the vocabulary of architectural planning and design $[19,20]$. The composition of building materials, similar to any substance, can be divided into mineral, organic, and combined (organic mineral) categories. The origin of building materials includes the processing depth of raw materials for their manufacture: natural materials are obtained by using materials found in the environment (wood, stone, sand, clay, etc.). The earth is our sustainer, the chain of ecological survival. Renewability is the key to our human continuum and our prime resource for architecture. Earth sheltering, earth handling, and earth escaping are more clearly pronounced in the vocabulary of architectural planning and design [21]. The ecology of building materials is a challenge to the effectiveness of current material use, as well as to the evaluation of new materials [22]. The new integrated science-environmental construction—should help solve the problems of creating and maintaining an environment of high-quality buildings. It is, therefore, right to use the words 'more or less' environment-friendly good or willing ecology [5]. There is a persistent pattern between the prevalence of the material and its harmfulness and toxicity. For example, water and earth (soil) are not toxic, and relatively rare elements such as lead, mercury, and cadmium are very dangerous for living 
organisms. According to this pattern, it is better to use raw materials and materials that are widely used for the construction of housing. In a mild, humid climate in wooded areas, the best material is, of course, wood. In hot areas, soil and clay are used, and in mountainous areas, the most common building material is stone $[23,24]$. Prior to the overdevelopment of the industry, builders naturally chose widespread, harmonious materials. The development of technology has greatly expanded the range of materials and structures. The use of innovative raw materials or the same materials produces with the use of innovative technology, optimized transport, and location of the manufacturing process [25].

Architecture is built for human inhabitation. In other words, architecture is built to be occupied by the human body (human bodies). As such, it makes sense that classical, Renaissance, modern, or contemporary architects would use the human body as an inspiration or principle of design [26]. Building materials have major influences on the building inhabitants, and environmental building materials add value to building jobs and decrease damaging effects on the environment [27]. The industrial construction approach has led to the widespread adoption of expensive and artificial building materials. Now, rarely does anyone turn to traditional materials if it is possible to use modern ones. From an environmental point of view, building materials can be divided into harmonious and inharmonious. Inharmonious materials are those whose presence has a negative effect on a person, and sometimes causes direct harm to health. Harmonious materials can be considered those that are widely distributed in nature [28]. Building Material Passports, in the construction process, are various classifications (Table 1) that can be considered: by the nature of the raw materials from which the materials are made, the generalities of the technological processes of their manufacture, functional purpose, and areas of application.

Table 1. Building Material Passport involving classification, process, and issues.

\begin{tabular}{|c|c|c|c|c|}
\hline No. & $\begin{array}{c}\text { Building Material } \\
\text { Passport }\end{array}$ & Classification & Process & Issues \\
\hline 1 & $\begin{array}{l}\text { Building materials } \\
\text { composition and } \\
\text { characteristic }\end{array}$ & & & \\
\hline 1.1 & $\begin{array}{l}\text { Technical data of } \\
\text { building materials }\end{array}$ & $\begin{array}{l}\text { Degree of preparedness, } \\
\text { origin, composition, raw } \\
\text { materials, destination }\end{array}$ & $\begin{array}{l}\text { Construction, repair, } \\
\text { reconstruction of } \\
\text { buildings }\end{array}$ & $\begin{array}{c}\text { Renewability, } \\
\text { ecological, } \\
\text { environment-friendly, } \\
\text { high quality }\end{array}$ \\
\hline 1.2 & Usage method & $\begin{array}{l}\text { Traditional, } \\
\text { affordable, new }\end{array}$ & $\begin{array}{c}\text { Sustainable } \\
\text { construction, } \\
\text { sustainable restoration }\end{array}$ & $\begin{array}{l}\text { Specific urban texture, } \\
\text { climatic condition, } \\
\text { thermal behavior }\end{array}$ \\
\hline 2 & $\begin{array}{c}\text { Contemporary } \\
\text { building materials }\end{array}$ & & & \\
\hline 2.1 & $\begin{array}{l}\text { Environmental } \\
\text { profile analysis }\end{array}$ & $\begin{array}{l}\text { Resource consumption, } \\
\text { energy consumption, } \\
\text { greenhouse effect, } \\
\text { acidification, nitrogen load, } \\
\text { human toxicity, disposal }\end{array}$ & Mineral, organic & $\begin{array}{l}\text { Renewable resources } \\
\text { from land or sea }\end{array}$ \\
\hline
\end{tabular}

\subsection{Environmental Impact on Building Materials and Conformations in a Hot Climate}

Buildings are constructed to meet recommended purposes; in one sense, they are buffers between man and his external thermal environment [29]. The thermal comfort of a building is closely associated with its building materials, which affect heat conduction, convection, and radiation. The UV-B content in sunlight is well known to adversely affect the mechanical properties of these materials, limiting their useful life [30]. Buildings in hot-dry regions are more likely to have sun-dried brick as the primary cladding material than are buildings in forest zones that utilize both sun-dried brick and timber. The earthworks found throughout Africa are commonly referred to as "mud houses" because the adobe work is not done in the traditional Western building method or the walls are raised when the brick material is still wet [31]. This has a negative connotation that distracts from 
the quality of the finished houses. African architecture is a product of many factors including geography, cultural heritage and assimilation, developmental policies, religious crusades, and political conquests [32]. The building elements in these houses are highly decorated, reproducing special typologies and traditional buildings [20]. Buildings can harm the environment and our health, for example, when using materials such as asbestos and lead-containing and toxic paints. Therefore, constructions using environmentally friendly materials have begun to be actively developed.

The vernacular buildings are compact with interior courtyards; the streets are sinuous and pass through the house volumes [33]. When designing buildings in a hot climate, it is necessary to consider the influx of thermal radiation from the sun, especially in the summer. The choice of building material should be based on its thermal inertia properties and, accordingly, on the delay time of the heat flux.

The extraction of raw materials is an important stage in the life cycle of a material. It is known that the stocks of some types of raw materials will be exhausted in a short (foreseeable) period if production continues at the current level. Clay, brick and straw, wood, and gravel are the most popular building materials used in constructions for which building materials and architectural solutions are more sustainable and environmentally friendly.

\subsection{Environmental Effect on Building Material Passport}

Currently, the concept of assessing building materials and their rational choice from the point of view of environmental and human safely is being introduced into the practice of architecture worldwide. New concepts are being introduced: an environmental assessment, the material life cycle (LCM), classification of materials according to environmental protection requirements, environmentally sound choice of building materials, etc. Within the framework of the global concept of "sustainable development," the task of creating an ecological worldview to solve global and private ecological problems of the human environment is being conducted. This position is defined in the international standards of the ISO (ISO) 14000 series "Environmental Quality Management System" and, in particular, the ISO 14040-14044 standards focused on the environmental quality of products. This approach is aimed at ensuring "sustainable construction" and "sustainable restoration," according to Oliveti et al. [34]. To solve the problem of the rational choice of materials for exterior and interior decorations of designed buildings in architectural practice, it is necessary to master the methodology of environmentally assessing materials according to the criteria of their safety for the environment and humans. Both new construction and restoration involve the use of various building materials that are more or less favorable to humans and do not equally affect the environment through the removal of natural resources and the introduction of pollutants. This negatively affects people's health and indirectly affects the quality of construction. Therefore, when designing, it is important to choose effective materials not only from economic and aesthetic viewpoints but also from an environmental standpoint. This requires an environmental assessment and classification of building materials in accordance with environmental requirements. In this case, when deciding on the use of a material, it is necessary to be able to assess its direct and indirect impacts on the environment and humans. Such an approach to this choice meets the requirements of the worldwide concept of "sustainable development," "sustainable construction," and "sustainable restoration" [35]. The destruction of the surface layers of the outer walls leads not only to the need for surface repair but can also lead to an overhaul of the entire fence. The effects of solar radiation on buildings can determine the suitable selection of building materials for the macro and microclimates. The city texture must reflect the climatic condition, and streets should maximize shelter from the wind for pedestrian comfort, maximize the dispersion of air pollutants, minimize urban warming to reduce the need for space cooling, and maximize solar access [36].

One of the most important effects on the durability of buildings is the outdoor climate in the summer, which has a pronounced alternating character. The changes in temperature and humidity directly affect the building structure and, to one degree or another, determine the choice of material and type of structures. First, it is the estimated outdoor temperature in the construction area during the cold season. 
The building's position on the site directly affects the material passport use in buildings, where the temperature, humidity, solar radiation, and wind are the most important factors that determine specific material uses in the building and covering layer, as shown in Figure 4. The site plane of any architectural element in a hot climate is a part of the microclimate study in which the most favorable orientation of the longitudinal axis of the building is north-south.

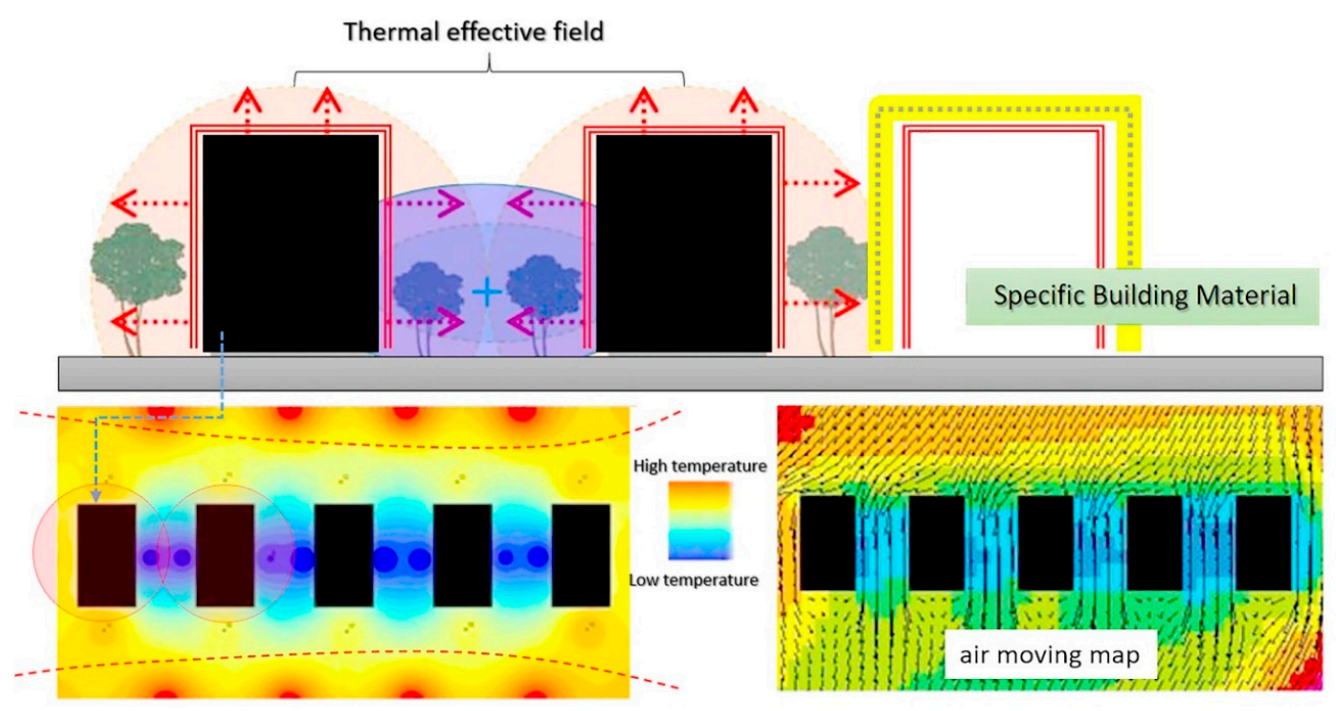

Figure 4. Building-Environment interaction on a local site.

Solar radiation affects the materials in various ways, depending on the parameters considered, location of testing, and type of materials, where the roof is the major building envelope that is directly exposed to solar heat radiation, subject to the location of the building. The impact of climate on the temperature and humidity states of the surface layers of structures is manifested in a large number of periods of warming and high solar radiation, which destroy the material from which the surface layers are made.

\section{Traditional Building Material Passport}

\subsection{Building Material Passport within Traditional Housing in Hot Climate}

Defining the characteristics for a material passport is a key step in creating a concept augmented matrix describing the most important features of a material passport [37]. Through an objective reading into the distant past and an attempt to imagine what materials ancient man could have used, it turns out that the choices were very modest: stones, clay, and wood. Today, these materials have not lost their relevance; they are called natural mineral (stones, clay) and natural organic (wood, hides) building materials. However, the possibilities for a modern builder are incommensurably higher; the assortment of materials and products intended for construction includes hundreds of thousands of items. They can serve various purposes; in other words, they have different purposes; for example, for erecting load-bearing and enclosing structures (structural materials and products) and for improving the operational, aesthetic, and special properties of buildings and structures (decoration, heat and waterproofing, roofing, radiation protection, and others). Until recently, buildings in hot climates were designed without any consideration for their energy efficiency by using specific building materials. For example, straw and clay as traditional building materials in hot climates have an efficient thermal effect upon buildings. According to a study by Sghiouri, Charai, Mezrhab et al., using clay and straw in a building reduces the indoor temperature by $5{ }^{\circ} \mathrm{C}$ on the warmest day of summer and reduces the total energy demand by $65 \%$ while decreasing the number of discomfort hours resulting from overheating by $25 \%$ [38]. Straw and clay play an important role in thermal efficiency and the 
formation of a healthy building. According to a study by David Y. K. Toguyeni et al., using a composite of these materials reduces the air conditioning load by approximately $8 \%$ compared to that in walled clay houses. As for the roof, the study also investigated the influence of the insulating materials on the air conditioning load. Hence, a $1.5 \mathrm{~cm}$ thick insulator made of redwood induces an energy savings of approximately $6.2 \%$ and a $12.1 \%$ savings on the air conditioning load for an insulation panel made of natural fiber and a lime-cement mixture [39].

\subsubsection{Brick as a Familiar Building Material}

Of all the building materials, brick is the most popular and versatile, largely due to the fact that brick made it possible to experiment with structures and create new forms. Currently, brick is the most common building material. Its versatility and practicality are appreciated throughout the world. It is known that the first people who built houses from unfired brick were the Sumerians (3000 BC). Figure 5 shows buildings that used brick as the main building material. Brick is divided into two main types, known even to non-specialists: ceramic brick made of clay and silicate brick made from sand, lime, and a number of additives $[20,40]$.

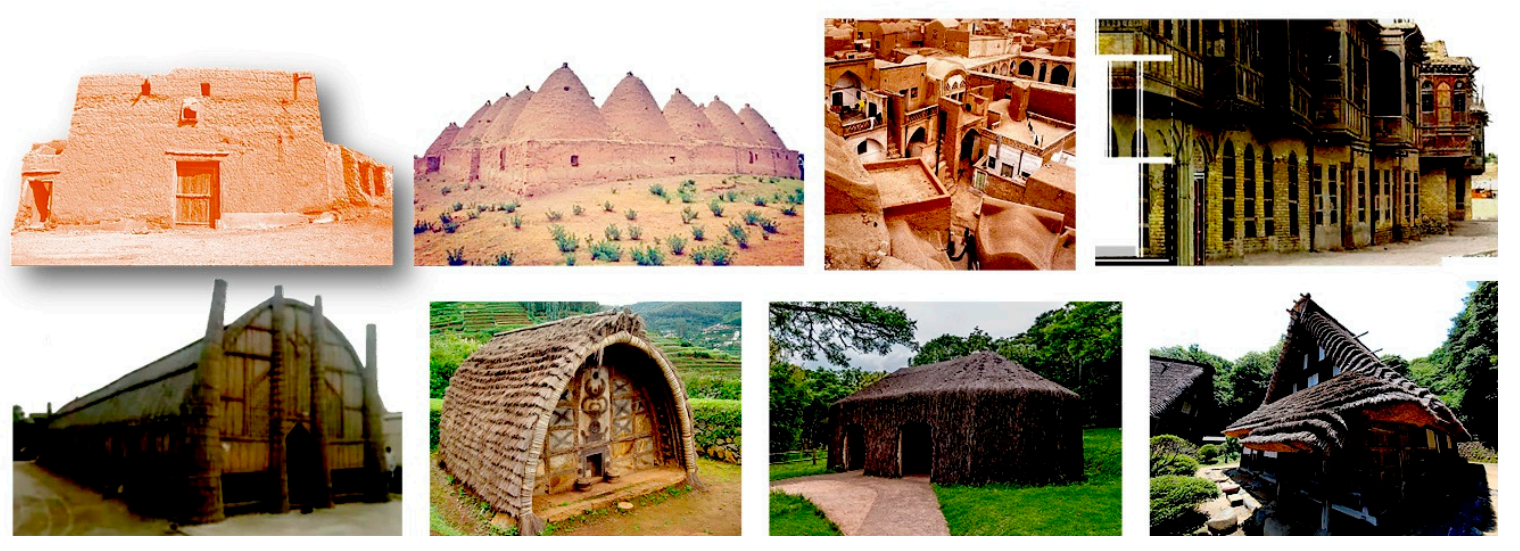

Figure 5. Traditional house from center of hot climate (the authors).

\subsubsection{Clay as Building Material in a Hot Climate}

The vast majority of modern buildings are constructed from highly processed materials, critically depleting global natural resources [41]. Today, it has become necessary to use natural building materials, specifically locally existing materials, as earthen building materials such as clay are minimally processed and inherently low carbon. As with other earthen construction materials and methods, cob was once a commonly used "vernacular" material in which renewed interest is growing and for which new modern construction applications are being realized, largely due to its various sustainability benefits [42]. Clay differs quite widely in composition from place to place, and the clay dug from one part of a field may well be quite different from that dug from another part of the same field. Clay is ground in mills, mixed with water to make it plastic, either by hand or machine, and shaped in the size of a brick [41,43]. In the hot and dry climate of Egypt, the abundance of silt and reeds determined the nature of building materials. Cane coated with clay and silt, burnt brick, and raw burnt brick from a mixture of silt and straw-these are the main building materials used in ancient Egypt. Thousands of old clay dwellings are still used as residences in the hot climate countries. In addition, adobe houses and clay mud huts still stand in villages throughout the country. Figure 6 shows traditional buildings made from local clay.

The dwellings in Ur, south of Iraq, which were built in 9000 BC from adobe bricks, still stand as a testament to the longevity of earthen houses [44]. Earth brick is a material that can resist earthquakes and is used in many earthquake-prone countries around the world such as Iraq, Pakistan, Iran, India, Thailand, China, and Mexico. 

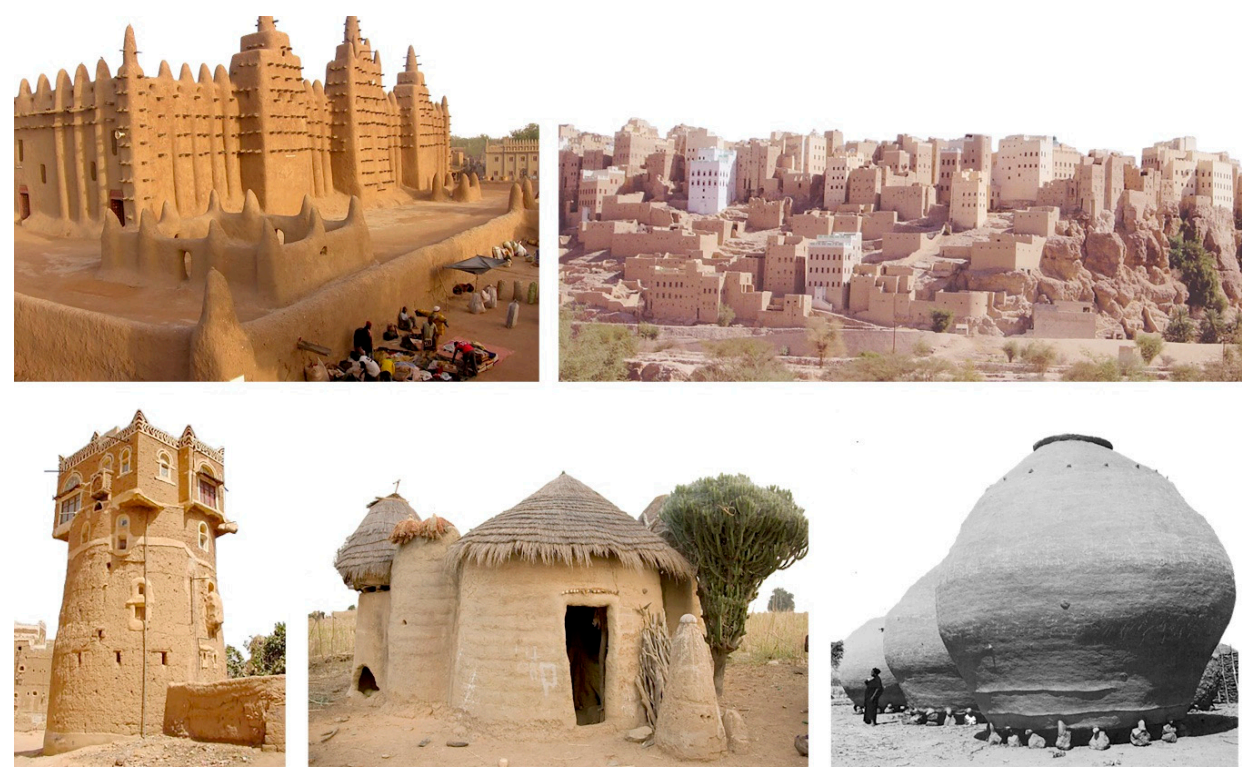

Figure 6. Traditional clay houses from a hot climate (the authors).

\subsubsection{Straw as a Main Building Material in a Hot Climate}

The construction of modern houses from straw, at first glance, has solid advantages. Indeed, it is difficult to find a more environmentally friendly and heat-saving building material than straw. However, there are a few caveats regarding the use of straw in construction related to its natural features. Before the building process, the straw must be thoroughly dried, otherwise it can rot in a couple of years. Straw blocks are pressed very tightly, and they need to be arranged so that the fibers are directed transversely to the outward movement of thermal energy [45]. The process of the building using straw blocks requires fire safety measures, like the stalks of straw scattered around the construction site (and this is almost inevitable) are very easily ignited without being compressed. The most optimal options are clay plaster or combined clay-cement. In a fairly thick straw wall, a large part of the convective transfer of thermal energy is very large. Straw refers to natural resources that are renewed very quickly. Figure 7 shows illustrations of the construction process of a vernacular house made of straw.
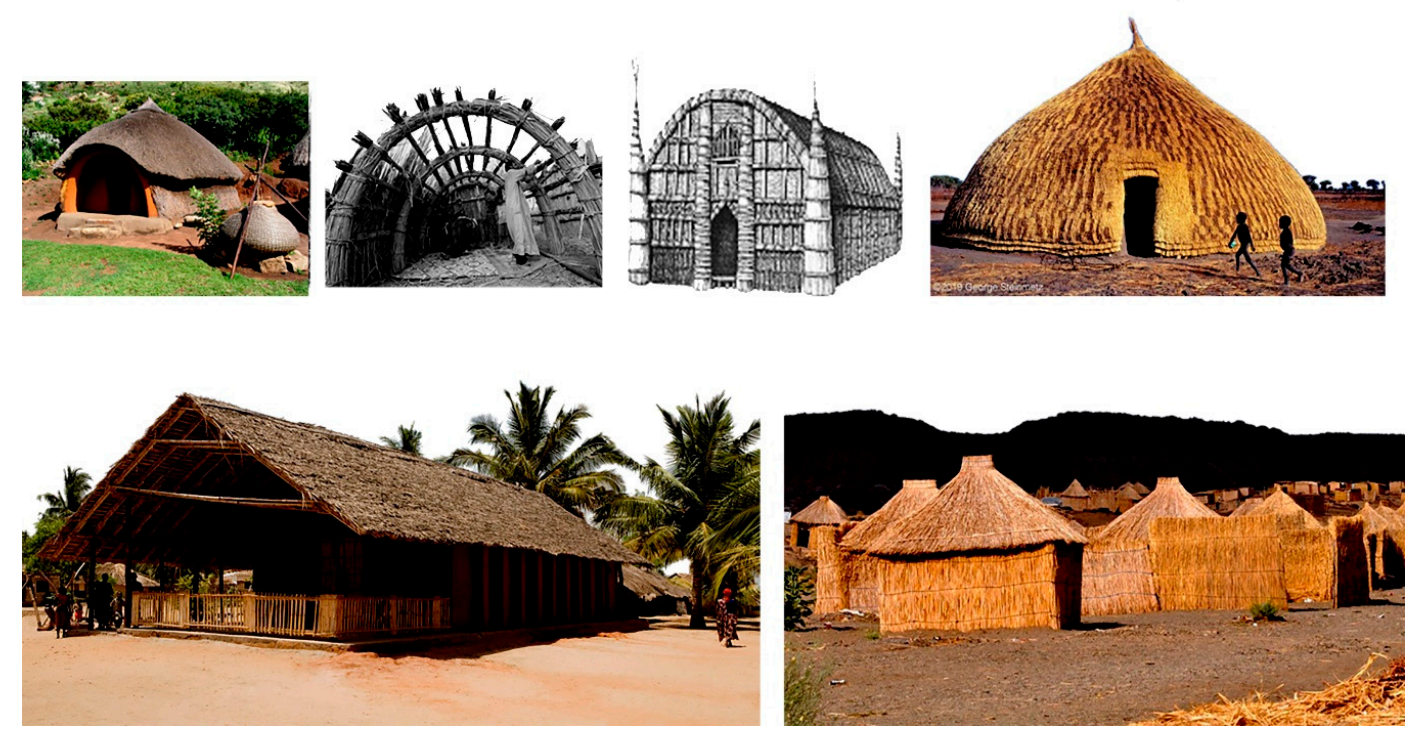

Figure 7. Compositions of clay and straw are the main building materials in the northern and eastern parts of Asia (the authors). 


\subsubsection{Wood as the Main Building Material in a Hot Climate}

Wood is an organic material, a natural composite of cellulose fibers (which are strong in tension) embedded in a matrix of lignin that resists compression. Wood is a heterogeneous, hygroscopic, cellular, and anisotropic material [46]. The earliest existing wooden buildings in China are the Nanzen Temple Hall of Wutai Mountain in Shanxi, built in 782 AD, and the East Hall of Foguang Temple, built in 857; there are few buildings in China built before the 15th century [47].

Wood is composed of cells, and the cell walls are composed of micro-fibrils of cellulose (40-50\%) and hemicellulose (15-25\%) impregnated with lignin (15-30\%). Figure 8 shows wood used in the creation of buildings in different hot climates. The thermal role of those elements is also a reflection of the sunlight and air current direction [20]. Wood is a good thermal insulator, and a 10-cm-wide piece of oak has a U-value between 0.07 and $0.1 \mathrm{~W} /(\mathrm{m} \cdot \mathrm{K})$. Figure 9 illustrates wood as the main building material in a hot climate.
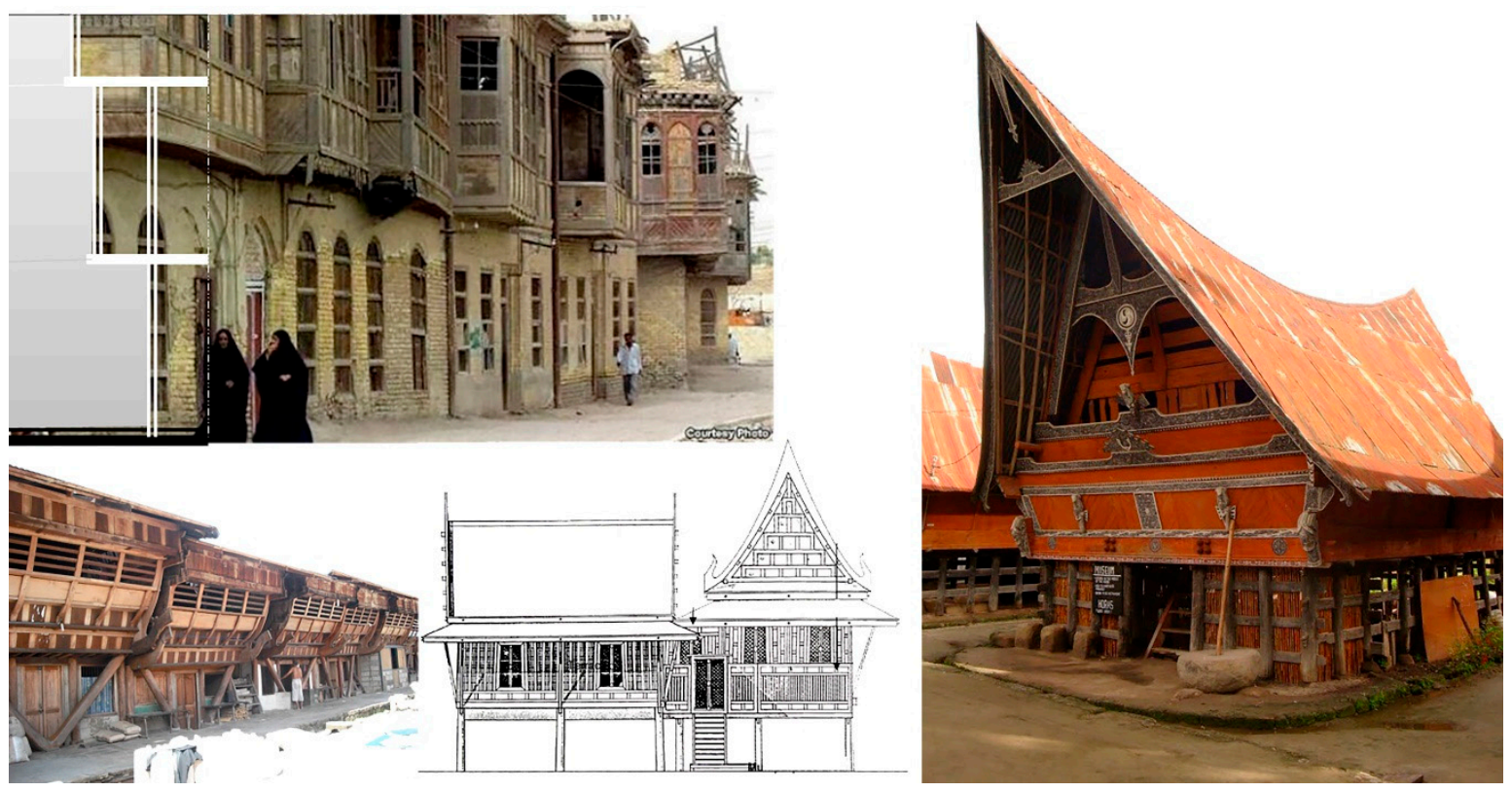

Figure 8. Wood as the main building material in a hot climate.

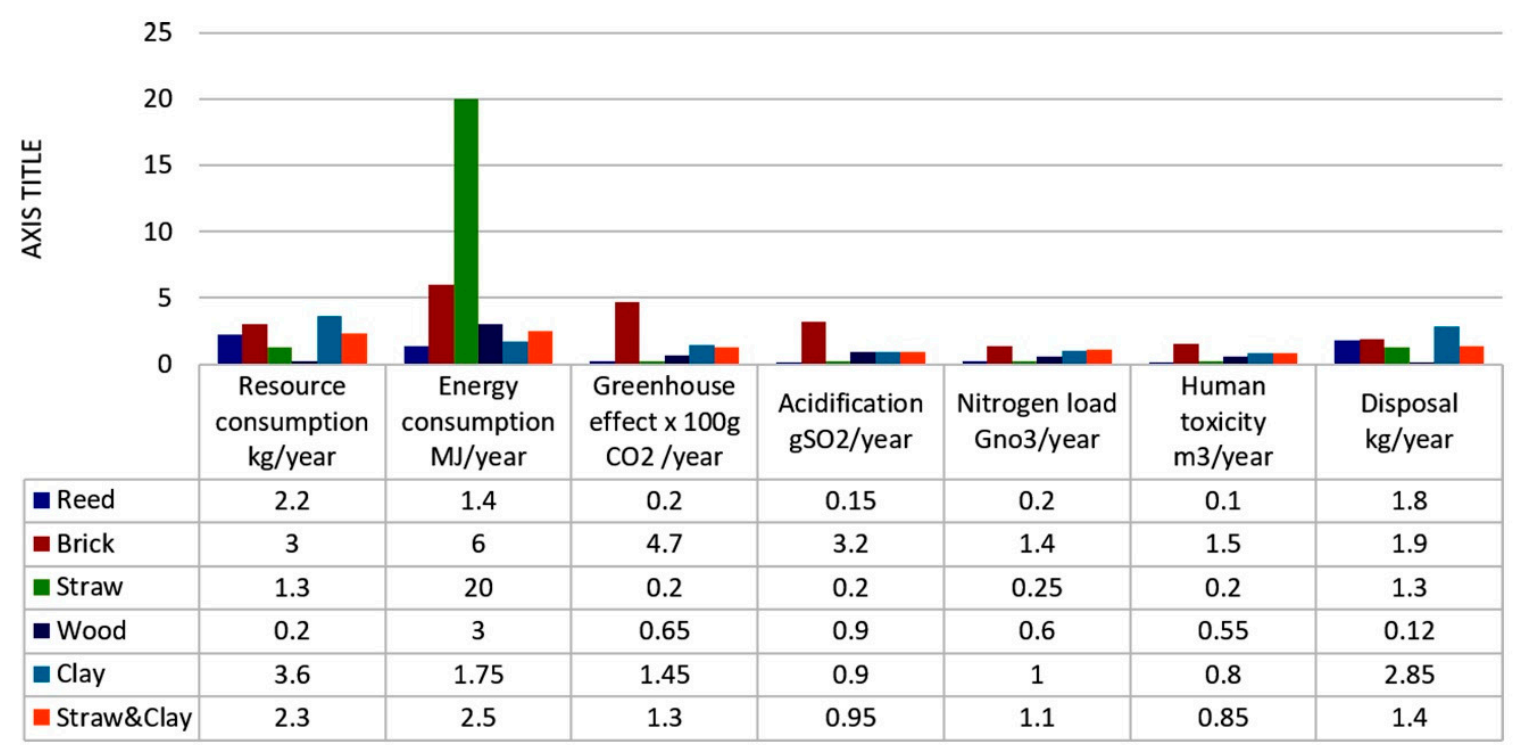

Figure 9. Environmental analysis of traditional building materials used in the construction process. 


\subsubsection{Gravel as an Environmental Building Material}

Gravel is the common name for stone and sand, erosion remnants of natural stone. According to the grain size, gravel is divided into ordinary (medium and large) and varietal (especially small, small, medium, large, especially large). Gravel is an important building material in the construction process in a hot climate. This material is used in foundations to reduce the negative effect of the water capillarity phenomenon.

\subsection{Environmental Profile Analysis for Traditional Building Materials}

The environmental profiles of all the described buildings, structures and materials consist of seven indicators covering the seven main quantifiable environmental impacts. The environmental profile indicators assess the building material's lifecycle by showing the various exchanges associated with the life cycle. There are also quantifiable environmental impacts beyond the seven listed. However, these are minor and are omitted for the benefit of a better understanding of the conditions that are primary [48]. In general, all building materials used in the construction process are ecological and environmentally friendly, and the analysis of these materials shows that their use can be successfully continued today. Figure 10 shows the results of an environmental profiles' analysis of anterior traditional building materials.

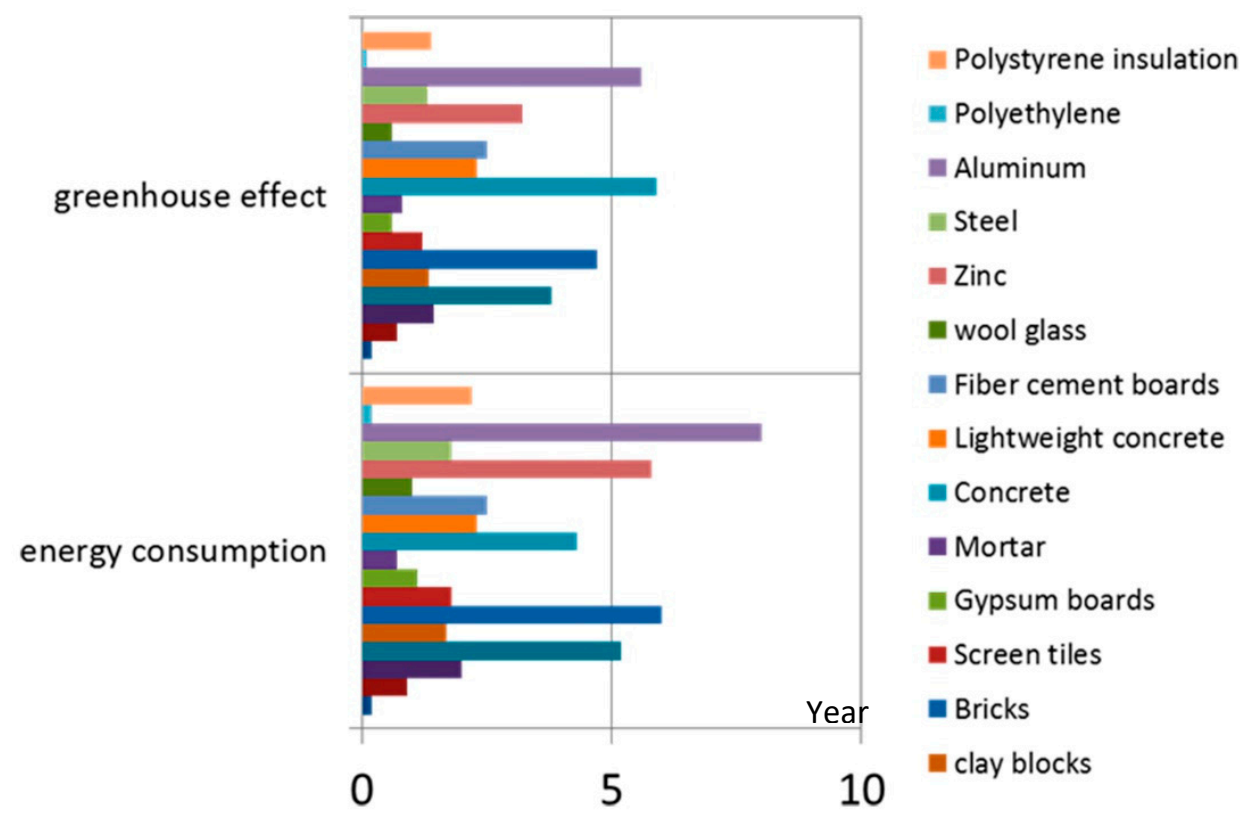

Figure 10. Environmental profile analysis for mineral building materials.

\section{A Review on a Contemporary Environmental Building Materials Chosen Process}

\subsection{What is the Interaction between Traditional and Modern Building Materials?}

The traditional building materials made of natural materials are classified after practical using requirements and the life cycle assignment, where all of these materials were used along the history without any negative consequences on the user's health. However, the new building materials represent a wide range of materials, which include many unhealthy materials, that can affect the human living environment negatively. Therefore, it is required to make a healthy passport material, that affects positively on the human-environment life. In this case, using traditional building materials provides us with a list of benefits upon physical and spiritual human life. Besides that, traditional materials inherit the atmosphere and style of ancient buildings. Applying traditional materials to modern buildings, 
complementing the two to complement each other and blending them into one, can make modern buildings have a new taste.

In addition to discussing building materials used in traditional vernacular buildings, it is also necessary to describe the most efficient building materials for creating a sustainable building design. Many researchers make a big effort to define the process of the material choosing process, where it is difficult to find a clear definition of what are the characteristics of sustainable building materials. Esin (2007) and Franzoni (2011) [49] point out that sustainable building materials are materials related to resource and energy efficiency in the manufacturing process, and these materials should have little pollution and no negative impact on human health. Abeysundara et al. [50] develop an evaluation matrix to help decision-makers balance environmental, economic and social factors in sustainable materials assessment. Anastaselos et al.'s research takes environmental, economic and social aspects into consideration during the thermal insulation evaluation [51].

All of us know a lot about why buildings make people sick or cause problems. One of the most apparent causes is using harmful materials (emits chemical emissions, fibers, allergens).

In the choice of materials, there are mainly two things to consider:

- How do the materials affect health and ecosystems?

- How do they affect resource use and environmental degradation?

When it comes to health, chemical content and emissions are crucial. When it comes to resource use, one must look at environmental profiles, developed with, for example, life cycle analyzes, where it represents a method of looking at materials' external environmental impact. It is calculated how much environmental degradation they have caused in the form of energy consumption and emissions to land, air and water. The problem with life cycle analyses is that they are time-consuming to perform and the result can be influenced more by the current production technology than by the material's properties. Life cycle analysis is also a suitable method for improving the production process. Modern requirements for building materials are determined primarily by the needs of people, design features of the premises, functionality, safety, durability, and environmental friendliness of buildings. Environmental friendliness is determined by the radon content in building materials. Indeed, over time, harmful substances will be released from non-environmentally friendly materials, thereby poisoning people living in these structures. Modern ecological building materials are made in such a way that the environment does not suffer. In other words, this is what nature itself gives us. Environmental friendliness is usually divided into absolute and conditional. Building materials with conditional environmental friendliness are made from natural raw materials: brick, glass, and tile. They are harmless to the environment but at the same time more high-tech. The choosing of building materials is very important in a building's life cycle assessment. The selection of building materials is not only closely related to the characteristic of building materials, and its behavior, which is determined before the production process, but also the overall energy consumption in the test of the operating stage. In the same time, it depends on the materials' potential to be recycled or reused, where the construction energy consumption can also be appropriately reduced [51].

\subsection{Contemporary Building Material Passport Description}

Building Material Passports are tools for buildings to incorporate a circular economy. The use of sustainable building materials represents a way for the construction industry to contribute to protecting the environment, and has become the key point to minimize the environmental impact and achieve sustainable development [51].

The contemporary Building Material Passport has been paid attention to in recent years when abruptly switched to a qualitative assessment of construction products. The impact of building activities on the environment is tremendous, where the building materials should be healthy for the inhabitants/users. That means they should be without pollutants and toxic components, not causing unpleasant noises, secure as radioactivity, and secure as electromagnetism [52]. There are thousands 
of contemporary building materials used today, but the most frequent building materials used in construction process are:

Clay blocks: They possess physical properties that are significantly different depending on whether they are normal or parallel to the bed face; therefore (also with respect to interlocking), clay block masonry cannot be treated in the same way as solid brick masonry in earthquake-resistant design. Additionally, the so-called pillow effect can occur due to the weak physical properties of clay blocks parallel to bed faces. This kind of material is popular because of the low cost of such buildings, due to the low cost of the materials, as well as the desire of modern people to be all-natural and environmentally friendly, and they can be used as masonry for construction [53].

Bricks: Bricks are made of clay. The clay tile is dried, preheated and burned at $800-1000{ }^{\circ} \mathrm{C}$ for about three hours. New is the so-called wax cake tile; the walls of this are no thicker than $2-3 \mathrm{~mm}$. It is made of particularly fine porous clay and thin cellulose fibers as pores. With wax cake tile, they have succeeded in achieving almost as good thermal insulation as that of lightweight concrete. Wax cake tile has thermal conductivity $\lambda=0.12 \mathrm{~W} / \mathrm{mK}$. Pore hole tile has $\lambda=0.20 \mathrm{~W} / \mathrm{mK}$. Bricks can be used as construction material, cladding tile, flooring and ground cover [54].

Concrete: Today, concrete has become the main material used in construction. Specialists select the concrete mix depending on the type and purpose of the structure being built. Properties that should be taken into account in concrete production are: heat properties and heat storage, sound insulating properties, frost breakdown, reinforcement corrosion and moisture properties. The majority of fluxes are melamine-based and contain formaldehyde. Concrete is heavy, stores heat well and has good sound absorption properties. An effective way to improve the fire resistance of the building structures is to apply heat-insulating coatings to the surface. One of the compositions to protect the structures from high temperatures is a heat-resistant solution based on the expanded clay sand and perlite [55]. It is fire-resistant, insulates poorly against cold, prevents moisture diffusion and absorbs moisture poorly. Moreover, they consider that the additional components that make up the solution contribute to improving the technical characteristics of most types of cement mixture. The production of cement is very energy-intensive and generates emissions of mainly $\mathrm{COx}$, $\mathrm{SOx}$ and $\mathrm{NOx}$ as well as small amounts of mercury. The cement industry has therefore devised methods to reduce its emissions. Types of concrete, which are presented in the market of modern building materials, are of high quality and variety [56]. Cement concretes are made on the basis of cementitious components. These types of solutions are made using cement ingredients [57].

Steel: Due to the high strength properties of steel in construction, it became possible to build taller houses, more spacious rooms, and lightweight but oversized structures (bridges, stadiums, etc.). In construction, stainless steel is used where it is impossible to protect steel products from direct exposure to water, for example, in various types of fasteners, external brackets, downpipes and ebbs, visors at porches, railings, and gratings. Stainless steel in construction is organically combined with most types of buildings and their finishing methods.

Aluminum: Aluminum is increasingly being recognized as an important material in the construction industry worldwide. Aluminum alloys as structural materials have several advantages that enable them to compete with steel in some types of building structures. The elastic modulus of aluminum and its alloys is approximately three times less than that of steels.

Zinc: Zinc probably came in to use around $500 \mathrm{BC}$. It has commonly been used as roofing material and later, to galvanize steel to provide corrosion resistance [57]. The properties of this material allow the use of zinc in many industries and in everyday life.

Glass: Transparent surfaces provide views, light and solar warmth [58]. Glass materials have an artificial amorphous structure, and they are obtained from a mineral melt containing glass-forming components (oxides of silicon, boron, aluminum, etc.).

Polystyrene insulation: This material is prepared from fossil oil. The oil is pumped up from underground reservoirs and shipped to the refinery. Both development and transport involve high risks to the environment, and the working environments notably carry an increased risk of cancer. 
The neurological supply horizon for fossil oil is approximately 90 years. Rock wool and glass wool are the most common polystyrene insulation material used.

Fiber cement: Fiber cement is a modern composite building material used for a wide range of finishing and construction work. This material consists of cement, cellulose reinforcing fiber, and mineral fillers. Building plates with a wide range of applications are made from fiber cement. A fiber cement sheet may be composed of $45 \%$ cement, $30 \%$ sand, and $8 \%$ micro silica, all abundant resources, with $10 \%$ water and $7 \%$ cellulosic fibers. The cellulosic fibers act as a reinforcement for the finished board. Plane fiber cement board is mainly used as exterior cladding; physically as a rain screen with an underlying ventilated cavity [59]. This material has exceptional characteristics: stable dimensions and mechanical strength with low weight, easy to install and cut, able to withstand heavy loads, and can be bent if necessary.

Gypsum board: This material consists of approximately $67 \%$ industrial gypsum, $28 \%$ cardboard, and small amounts of corn starch and other additives. Gypsum board is non-combustible and fire-resistant in the sense that the plaster by fire again will calcite, which release water calcination that will be slow already at temperatures above $45^{\circ} \mathrm{C}$. Plasterboard has a moderate thermal conductivity and open vapor but cannot tolerate wetting [60]. Although gypsum can dehydrate to a hemihydrate, the mineral basanite, and to an anhydrate, the mineral anhydrite, this reaction occurs in nature on a geological time scale and, therefore, it is unlikely to occur when gypsum is found on and in building materials [61].

Glass wool: This material is made of glass fibers of approximately $30 \%$ silica sand and close to $30 \%$ dolomite, borax, nepheline, and limestone together, all naturally occurring substances. In addition, it includes approximately $10 \%$ soot produced chemically and 30\% cullet [62,63]. Glass wool is classified as non-combustible or having a limited combustibility depending on the binder content. While it will lose small $(\sim 5 \%)$ quantities of pyrolysable binders, most of the mass will not burn, and there is insufficient fuel for a flame to propagate through the bulk of the material; therefore, their contribution to the fuel load is negligible $[64,65]$. The proportion of broken glass can be increased to $70 \%$, by which the consumption of raw materials and energy is reduced [66]. Glass wool is mainly used for the thermal insulation of walls, ceilings, and roofs.

Other building materials: Other material can be used in the construction process, such as perlite, lightweight concrete, lightweight aggregate, screen tiles, polyethylene, carpentry, paper wool bales, flax insulation, joinery timber, particleboard plywood, paper wool, hardboard, cedar, and larch.

\subsection{Environmental Profile Analysis of Frequent Contemporary Building Materials}

The production of building materials can be very complex, and the theoretical basis for environmental assessment has made slow progress [6]. With the lack of theory and limited data, it has been very difficult to make objective assessments, and it is only in recent years that effective models for the environmental assessment of materials have been available. In general, modern building materials are divided into two main groups: the mineral and the organic [67]. It is valuable from an environmental perspective to gain knowledge of all types of materials and how they function in various environments, both individually and together. They can be divided into mineral materials such as stone, concrete, glass and lime; organic materials such as wood and cellulose fiber; metals; and synthetic materials such as plastic [10]. Then, the materials are grouped based on the dominant feedstock. In each subgroup, progression is sought from materials with a low processing level to those with a higher degree of processing.

\subsubsection{Mineral Materials}

Mineral materials are made from renewable resources from the land or sea. Table 2 shows classifications of mineral building materials. 
Table 2. Classifications of mineral building materials.

\begin{tabular}{|c|c|c|c|c|c|}
\hline Stone-Based & Clay-Based & Gypsum-Based & Cementitious & Metals & Oil-Based \\
\hline Gravel & $\begin{array}{l}\text { Lightweight } \\
\text { aggregate }\end{array}$ & Gypsum-boards & Mortar concrete & Zinc & Polyethylene \\
\hline Perlite & Clay blocks & & Concrete & Steel & $\begin{array}{l}\text { Polystyrene } \\
\text { insulation }\end{array}$ \\
\hline $\begin{array}{c}\text { Glass } \\
\text { Glass wool }\end{array}$ & $\begin{array}{c}\text { Bricks } \\
\text { Screen tiles }\end{array}$ & & $\begin{array}{l}\text { Lightweight concrete } \\
\text { Fiber cement boards }\end{array}$ & Aluminum & \\
\hline
\end{tabular}

The modern building includes a wide variety of mineral materials based on natural and composite substances, the combination of which can take human health into consideration. Today, the environmental profile can be a tool to create a safer building. The values for two categorical effects are presented in Figure 11: the greenhouse effect and the energy consumption for different mineral building materials. Sustainable buildings require the avoidance of harmful substances and use local materials with an excellent environmental profile.

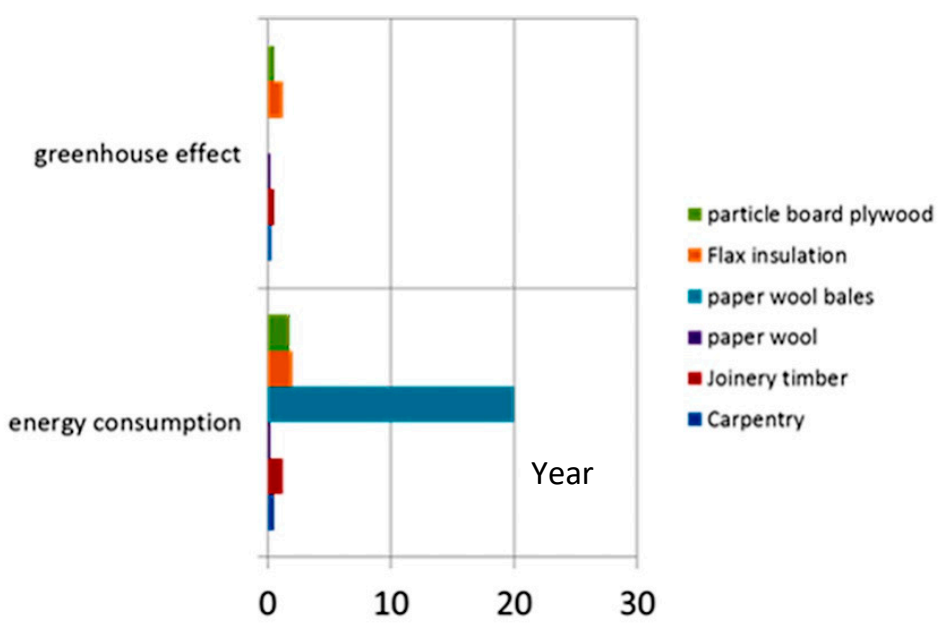

Figure 11. Environmental profile analysis for organic building materials.

\subsubsection{Organic Materials}

Organic materials are mainly made from renewable resources. Table 3 shows mineral building materials' classifications.

Table 3. Classifications of organic building materials.

\begin{tabular}{ccc}
\hline Woody & Straw-Based & Flax-Based \\
\hline Carpentry & Paper wool bales & Flax insulation \\
Joinery timber & & \\
Particleboard plywood & & \\
Paper wool & & \\
Hardboard & & \\
Cedar & \\
Larch & \\
Carpentry & \\
\hline
\end{tabular}

Figure 11 illustrates the environmental profile analysis for organic building materials. 


\section{Results and Conclusions}

Today it becomes necessary to create and build a material passport adequate for each climate area, and it is required to limit usage of building materials with a negative impact on the environment. It may be necessary to handle and supply information to stakeholders in the value chains of industry and facilitate the creation of more sustainable and resilient cities in which inventory resources are stored, removed, and reused to maintain, retrieve, or improve the value and useful living [68]. Building Material Passports are collections of information and indicators describing material and system characteristics that give them value for recovery and reuse $[69,70]$. This provides the material's history documentation, such as details received by the producers and requirements of the material after use [71]. It is thus a tool for integrating data and information into circularity support, focusing on the recovery at the end of life and value maximization of the materials [69].

The quality of the building creation has influenced the choice of building material, from which all building materials selected should be used, after their environmental characteristic, which is more favorable for humans, as well as different influences on the environment. It is important to choose effective materials from an environmental point of view. This requires environmental assessment and classification of construction materials according to the requirements of the protection of the environment. Building materials emit a variety of emissions. Limit values exist only for some of them, and knowledge of the collaborative effects of various substances is poor. Toxic elements that are quietly emitted by poor-quality coatings, wood-based panels, paints, and furniture are capable of poisoning the structure's atmosphere, causing significant harm to health. It is important to remove as many unpleasant chemicals as possible from the construction industry as chemicals can be risky in several ways. Vernacular architecture offers us a precious material corresponding to the new requirements. The real subject that requires an objective discussion is the environmental impact on building creation and resource consumption, which may differ from indicator to indicator. As an example, wood has a low climate impact but a high content of embedded energy. The discussion above has illustrated that the essential element of good building materials is the avoidance of problematic substances in the construction that can adversely affect the environment, health, and recycling opportunities. It is a challenge to select suitable materials that correspond to hot climates, in which the materials are directly affected. Reuse and recycling of building materials and consumption of reclaimed and recycled building materials as environmental practices have potential to enhance resource efficiency in the construction industry, leading to a reduction in the amount of waste produced and energy consumed [72]. A different classification of healthy building material will support a sustainability strategy for ecological buildings. Many of the problems are common to products from all sectors, and research has been ongoing in many of these areas for some time. It is unfortunate that some of the issues that are most relevant to construction materials, such as environmental profiles for selecting building materials, are requirements to be devolved. In the longer term, it seems likely that the most accurate information will be available to architects in the form of profiles for an entire design, based on partly classified inventory data. In the short term, firm profiles will be made available for material and product choices made in "quick-fix" situations. Considering the energy aspects provides a different result. During its growth, wood absorbs solar energy. At the end of its life, this embedded energy can be utilized for renewable energy production by combustion. An environmental benefit is obtained if biomass replaces fossil fuels. The relatively high primary energy content of the tree can, therefore, be explained by the fact that the tree is not only a building material but also a renewable energy resource. Another significant explanation for variations in results is due to the differences in the densities of the structures. The density varies when the material must fulfil different functions in the building. The relatively high climatic load of fiber-based pressure-resistant insulation is often due to an elevated density compared to the soft application of a skeletal structure. In this case, material consumption is further increased with a greater thickness. Today, it has become necessary to recommend eco-friendly passport materials such as clay bricks, which are made from natural components: a mixture of limestone and sand. Brick is one of the most reliable and aesthetic building materials. Natural wood is in the 
form of profiled beams or logs. Many traditional building materials can be used in the construction of buildings as a formwork, structural material, or insulation, such as lightweight and durable blocks of reeds or straw, in which clay is used as a binder. Small farm buildings can be built from reed and straw in a hot climate.

The study demonstrated that the use of passport materials has to be controlled according to the environmental profile model, which assesses the impacts of materials on the environment, that becomes a requirement for selecting building materials based on required proprieties. The study discusses the requirements of Building Material Passports in hot climates. All construction must be resistant, stable, and durable to the various operational demands. These conditions can be ensured by choosing and using the appropriate building materials. In the current conditions, choosing building materials becomes more complicated when the consideration of not only their appearance, strength and cost but also safety is required.

When choosing materials from an environmental and health point of view, various building materials are described, partly about chemical content and partly their environmental impact from a life cycle perspective. The study makes a weighted assessment of the materials that cause the least impact on the environment and health. The choice of safe materials for construction help not only to reduce the negative impact of buildings on the environment but also improve the indoor space of the buildings.

Author Contributions: Conceptualization, A.A. (Amjad Almusaed) and A.A. (Asaad Almssad); methodology, A.A. (Amjad Almusaed); software, A.A. (Asaad Almssad); validation, A.A. (Amjad Almusaed), A.A. (Asaad Almssad) and I.Y.; formal analysis, A.A. (Amjad Almusaed); investigation, A.A. (Asaad Almssad); resources, R.Z.H.; data curation, A.A. (Asaad Almssad); writing—original draft preparation, A.A. (Amjad Almusaed); writing-review and editing, I.Y.; visualization, A.A. (Amjad Almusaed); supervision, A.A. (Amjad Almusaed); project administration, A.A. (Amjad Almusaed); funding acquisition, A.A. (Amjad Almusaed). All authors have read and agreed to the published version of the manuscript.

Funding: This research received no external funding.

Conflicts of Interest: The authors declare no conflict of interest.

\section{References}

1. Allacker, K.; Debacker, W.; Delem, L.; De Nocker, L.; De Troyer, F.; Janssen, A.; Peeters, K.; Servaes, R.; Spirinckx, C.; Van Dessel, J. Environmental profile of building elements. Stationsstraat 2013, 110, 5-6.

2. Skoczylas, K.; Rucińska, T. Influence of Grain Shape of Waste Glass Aggregate on the Properties of Cement Mortar. J. Ecol. Eng. 2020, 21, 148-159. [CrossRef]

3. Pearlmutter, D.; Theochari, D.; Nehls, T.; Pinho, P.; Piro, P.; Korolova, A.; Papaefthimiou, S.; Mateo, M.C.; Calheiros, C.; Zluwa, I.; et al. Enhancing the circular economy with nature-based solutions in the built urban environment: Green building materials, systems and sites. Blue-Green Syst. 2020, 2, 46-72. [CrossRef]

4. Romero-Odero, J.A.; Galán-Marín, C.; Rivera-Gómez, C. Atrium Impact on a School-Building: Thermal Performance in a Hot Climate. Multidiscip. Digit. Publ. Inst. Proc. 2019, 38, 18. [CrossRef]

5. Doran, D.; Cather, B. Construction Materials Reference Book, 2nd ed.; Routledge: Abingdon, UK, 2013.

6. Rajan, V.S.; Sasikumar, A.; Kumar, R.J.; Mohanalakshmi, V.; Scholar, P.G. Innovative Brick Manufacturing using Papercrete. Int. J. Contemp. Eng. Sci. Emerg. Technol. 2020, 1, 464.

7. Almusaed, A.; Almssad, A. Urban Biophilic Theories upon Reconstructions process for Basrah City in Iraq. In Proceedings of the Passive and Low Energy Architecture Conference, PLEA, Ahmad Abad, India, 12 December 2014.

8. Honic, M.; Kovacic, I.; Rechberger, H. Concept for a BIM-based Material Passport for building. In Proceedings of the IOP Conference Series: Earth and Environmental Science, Volume 225, SBE19 Brussels-BAMB-CIRCPATH "Buildings as Material Banks-A Pathway for A Circular Future", Brussels, Belgium, 5-7 February 2019.

9. Almusaed, A.; Almssad, A. Building materials in eco-energy houses from Iraq and Iran. Case Stud. Constr. Mater. J. 2015, 2, 42-54. [CrossRef] 
10. Block, M.; Bokalders, V. The Whole Building Handbook: How to Design Healthy, Efficient and Sustainable Buildings, 1st ed.; Routledge: Abingdon, UK, 2009; pp. 9-14.

11. Di Maria, A.; Snellings, R.; Alaert, L.; Quaghebeur, M.; Van Acker, K. Environmental assessment of $\mathrm{CO}_{2}$ mineralization for sustainable construction materials. Int. J. Greenh. Gas Control 2020, 93, 102882. [CrossRef]

12. Cascone, S.M.; Cascone, S.; Vitale, M. Building Insulating Materials from Agricultural By-Products: A Review. In Sustainability in Energy and Buildings. Smart Innovation, Systems and Technologies; Littlewood, J., Howlett, R., Capozzoli, A., Jain, L., Eds.; Springer: Singapore, 2020; Volume 163.

13. Homod, R.Z. Analysis and Optimization of HVAC Control Systems Based on Energy and Performance Considerations for Smart Buildings. Renew. Energy 2018, 126, 49-64. [CrossRef]

14. Homod, R.Z. Review on the HVAC System Modeling Types and the Shortcomings of Their Application. J. Energy 2013, 2013, 768632. [CrossRef]

15. Brown, L.R. State of the World; World Watch Institute: Washington, DC, USA, 1990.

16. Sahari, K.M.; Jalal, M.A.; Homod, R.Z.; Eng, Y.K. Dynamic indoor thermal comfort model identification based on neural computing PMV index. In IOP Conference Series: Earth and Environmental Science; IOP Publishing Ltd.: Bristol, UK, 2013; Volume 16, p. 012113.

17. Almusaed, A.; Almssad, A. Biophilic Architecture: The Concept of Healthy, Sustainable Architecture. In Proceedings of the PLEA 2006: 23rd International Conference on Passive and Low Energy Architecture, Geneva, Switzerland, 6-8 September 2006.

18. Possenti, E.; Colombo, C.; Conti, C.; Gigli, L.; Merlini, M.; Plaisier, J.R.; Realini, M.; Sali, D.; Gatta, G.D. Diammonium hydrogen phosphate for the consolidation of building materials. Investigation of newly-formed calcium phosphates. Constr. Build. Mater. 2019, 195, 557-563. [CrossRef]

19. Almusaed, A.; Almssad, A. Thermal earth inertia such a source of energy for bio-sustainable house. In Proceedings of the 2005 World Sustainable Building Conference, (SB05Tokyo), Tokyo, Japan, 27-29 September 2005.

20. Almusaed, A. Intelligent Sustainable Strategies Upon Passive Bioclimatic Houses; Arkitektskole i Aarhus: Aarhus, Denmark, 2004; pp. 156-160.

21. Almusaed, A.; Almssad, A.; Alasadi, A. Analytical interpretation of energy efficiency concepts in the housing design. J. Build. Eng. 2019, 21, 254-266.

22. Dinesen, J.; Krogh, H.; Traberg-Borup, S. Livscyklusbaseret Bygningsprojektering: Opgørelse af Bygningers Energiforbrug og Energirelaterede Miljøpåvirkninger; SBI-rapport 279 Statens Byggeforskningsinstitut 1997; SBI Forlag: Hørsholm, Denmark, 1997.

23. Almusaed, A. Improvement of Thermal Insulation (Passive Buildings). In Biophilic and Bioclimatic Architecture; Springer: London, UK, 2001.

24. Almusaed, A.; Almssad, A. Introductory Chapter: Housing Policy Matters. In Housing; Almusaed, A., Almssad, A., Eds.; IntechOpen: London, UK, 2018.

25. Michałowski, B.; Marcinek, M.; Tomaszewska, J.; Czernik, S.; Piasecki, M.; Geryło, R.; Michalak, J. Influence of Rendering Type on the Environmental Characteristics of Expanded Polystyrene-Based External Thermal Insulation Composite System. Buildings 2020, 10, 47. [CrossRef]

26. Smith, K.; Guitart, M. (Eds.) Introducing Architectural Theory: Debating a Dizscipline; Routledge, Taylor \& Francis: London, UK, 2012.

27. Friedman, L. Green Buildzing Materials City of Santa Monico; Energy and Green Building Program "City of Sant Monica" Publishing: California, CA, USA, 2000; p. 6.

28. Siegrist, C.R. Utility Community Solar Handbook; Solar Electric Power Association SEPA: Washington, DC, USA, 2013; pp. 213-215.

29. Hata, R.M.; Hassan, R.; Arshad, F.; Idayu, H. Effect of Solar Radiation to the Building Materia. Sci. Res. J. 2016, 13, 29-43. [CrossRef]

30. Andrady, A.L.; Hamid, S.H.; Hu, X.; Torikai, A. Effects of increased solar ultraviolet radiation on materials. J. Photochem. Photobiol. B Biol. 1998, 46, 96-103. [CrossRef]

31. Jensen, A.A.; Elkington, J.; Christiansen, K.; Hoffmann, L.; Moller, B.T.; Schmidt, A.; van Dijk, F. Life Cycle Assessment: A Guide to Approaches, Experiences and Information Sources; Environmental Issues Series no. 6; European Environment Agency: Copenhagen, Denmark, 1997.

32. Elleh, N. African Architecture Evolution and Transformation; McGraw-Hill: New York, NY, USA, 1996. 
33. Almusaed, A. The Functional Roles of the Patio in the Warm, Dry Zone (e.g. Iraq). In A.D Review; Ion mincu: Bucharest, Romania, 1997; Volume 2, pp. 53-55.

34. Oliveti, G.; Arcuri, N.; Ruffolo, S. Experimental investigation on thermal radiation exchange of horizontal outdoor surfaces. Build. Environ. 2003, 38, 83-89. [CrossRef]

35. Bjerg, S.N.; uderum, V.I. Klimalaboratoriet, Aarhus, Indvendigt Anvendelse; Arkitektskole i Aarhus: Aarhus, Denmark, 2010; p. 22.

36. Ignatius, M. Urban Texture Analysis and Its Relation to Building Energy Consumption. Ph.D Thesis, National University of Singapore, Singapore, 2014; p. 43.

37. Verdinelli, S.; Scagnoli, N.I. Data Display in Qualitative Research. Int. J. Qual. Methods 2013, 12, $359-381$. [CrossRef]

38. Sghiouri, H.; Charai, M.; Mezrhab, A.; Karkri, M. Comparison of passive cooling techniques in reducing overheating of the clay-straw building in semi-arid climate. Build. Simul. 2020, 13, 65-88. [CrossRef]

39. Toguyeni, D.Y.; Coulibaly, O.; Ouedraogo, A.; Koulidiati, J.; Dutil, Y.; Rousse, D. Study of the influence of roof insulation involving local materials on cooling loads of houses built of clay and straw. Energy Build. 2012, 50, 74-80. [CrossRef]

40. Almusaed, A.; Almssad, A. Introductory Chapter: Overview of Sustainable Cities, Theory and Practices; Almusaed, A., Almssad, A., Eds.; InTech.: London, UK, 2019; Chapter 1.

41. Yamamoto, J. Buildings and Climate Change; summary for decision-makers; Sustainable Buildings \& Climate Initiative, United Nations Environment Programme: Nairobi, Kenya, 2009; pp. 43-51.

42. Ben-Alon, L.; Loftness, V.; Harries, K.A.; DiPietro, G.; Hameen, E.C. Cradle to site Life Cycle Assessment (LCA) of natural vs conventional building materials: A case study on cob earthen material. Build. Environ. 2019, 160, 106150. [CrossRef]

43. Reddy, B.V.; Jagadish, K.S. Embodied energy of common and alternative building materials and technologies. Energy Build. 2003, 35, 129-137. [CrossRef]

44. Almusaed, A. Town texture specific for the warm zone. In A.D Review, Issue nr 12-1996; Ion Mincu: Bucharest, Romania, 1996.

45. Ahmed, M.S.; Mohamed, A.; Khatib, T.; Shareef, H.; Homod, R.Z.; Ali, J.A. Real-Time Optimal Schedule Controller for Home Energy Management System Using New Binary Backtracking Search Algorithm. Energy Build. 2017, 138, 215-227. [CrossRef]

46. Wenzel, H. Miljøvurdering af produkter. In UMIP Udvikling af Miljøvenlige Industriprodukter; Miljø- og Energiministeriet: København, Denmark, 1996.

47. Goodrich, L.C. A Short History of the Chinese People; Sturgis Press: Sydney, Australia, 2007.

48. Marsh, R. Arkitektur og Miljø, from Konstruktion Materialer-Og Miljøpåvirkning, Arkitektskolens Forlag; Arkitektskol i Aarhus: Aarhus, Denmark, 2000; p. 118.

49. Esin, T. A study regarding the environmental impact analysis of the building materials production (in Turkey). Build. Environ. 2007, 42, 3860-3871. [CrossRef]

50. Abeysundara, Y.; Babel, S.; Gheewala, S. A matrix in life cycle perspective for selecting sustainable materials for buildings in Sri Lanka. Build. Environ. 2009, 44, 997-1004. [CrossRef]

51. Songa, Y.; Zhang, H. Research on sustainability of building materials. In IMMAEE 2018 IOP Conference Series: Materials Science and Engineering; IOP Publishing Ltd.: Bristol, UK, 2018; Volume 452.

52. Bica, S.M.; Roşiu, L.I.; Radoslav, R.A. What Characteristics Define Ecological Building Materials. In Proceedings of the 7th IASME/WSEAS International Conference on Heat Transfer Thermal Engineering and Environment-HTE 2009, Moscow, Russia, 20-22 August 2009.

53. Thamboo, J.A. Material characterization of thin layer mortared clay masonry. Constr. Build. Mater. 2020, 230, 116932. [CrossRef]

54. Wheaton, W.C.; Tung, E. Bricks or Clicks? The Efficiency of Alternative Retail Channels; SSRN Publisher: Cambridge, UK, 2019.

55. Khadzhishalapov, G.N.; Hajiyev, A.M.; Khezhev, T.A.; Alimuradov, S.A. Heat Resistant Light Solutions on the Activated Composite Binder from the Local Mineral Raw Materials. Mater. Sci. Forum 2019, 974, 400-405. [CrossRef]

56. Khokhar, R. A Study of green concrete. Int. J. Technol. Res. Eng. 2020, 7, 6431-6433.

57. Berge, B. The Ecology of Building Materials; Elsevier's Science \& Technology: Oxford, UK, 2009; p. 194. 
58. Shadmon, A. Mineral Structural Materials. In AGID Guide to Mineral Resources; Association of Geoscientists for International Development: Bangkok, Thailand, 1983.

59. Punmia, B.C.; Komar, A.; Komar, A. Building Construction, Firewall Media; Laxmi publishing LTD.: Delhi, Indea, 2005; p. 213.

60. Allen, E.; Iano, J. Fundamentals of Building Construction: Materials and Methods; Wiley: Hoboken, NJ, USA, $2011 ;$ p. 213.

61. Charola, A.E.; Pühringer, J.; Steiger, M. Gypsum: A review of its role in the deterioration of building materials. Environ. Geol. 2007, 52, 339-352. [CrossRef]

62. Jester, T.C. Twentieth-Century Building Materials: History and Conservation; McGraw-Hill: New York, NY, USA, 1995.

63. Standard Specification for Glass Fiber Strands; D 578-05, Annual Book of ASTM Standards. 2005. Available online: http://209.195.157.233/download/D578-05.15243.pdf (accessed on 29 April 2020).

64. Stec, A.A.; Hull, T. R Assessment of the fire toxicity of building insulation materials. Energy Build. 2011, 43, 498-506. [CrossRef]

65. Almusaed, A.; Almssad, A. Environmental reply to vernacular habitat conformation from a vast areas of Scandinavia. Renew. Sustain. Energy Rev. J. 2015, 48, 825-834. [CrossRef]

66. Almusaed, A.; Almssad, A. Introductory Chapter: Overview of a Competent Sustainable Building, Sustainable Buildings_Interaction between a Holistic Conceptual Act and Materials Properties; Almusaed, A., Almssad, A., Eds.; Sustainable Buildings; InTech.: London, UK, 2018.

67. Slessor, C.; Linden, J. Eco-Tech: Sustainable Architecture and High Technology; Thames \& Hudson: London, UK, 2007.

68. Munaro, M.R.; Fischer, A.C.; Azevedo, N.C.; Tavares, S.F. Proposal of a building material passport and its application feasibility to the wood frame constructive system in Brazil. In IOP Conference Series: Earth and Environmental Science; IOP Publishing: Bristol, UK, 2019; Volume 225, p. 012018.

69. Douglas, M.; Katja, H.; Lars, L.; Rafaela, Z.; Raymond, W.; Jan, B.; Lisa, E.; Matthias, H.; Werner, L. Framework for Material Passports. Available online: https://www.bamb2020.eu/wp-content/uploads/2018/ 01/Framework-for-Materials-Passports-for-the-webb.pdf (accessed on 29 April 2020).

70. Luscuere, L. Materials Passports: Optimising value recovery from materials. In Waste and Resource Management; ICE Publishing: London, UK, 2016; Volume 170.

71. Jensen, K.G.; Sommer, J. Building a Circular Future; GXN Innovation: Copenhagen, Denmark, 2016; p. 284.

72. Balador, Z.; Gjerde, M.; Isaacs, N. Influential Factors on Using Reclaimed and Recycled Building Materials. In Sustainability in Energy and Buildings. Smart Innovation, Systems and Technologies; Littlewood, J., Howlett, R., Capozzoli, A., Jain, L., Eds.; Springer: Singapore, 2020; Volume 163. 